\title{
Current State of Dendritic Cell-Based Immunotherapy: Opportunities for in vitro Antigen Loading of Different DC Subsets?
}

\author{
Anne Huber ${ }^{1}$, Floris Dammeijer ${ }^{1,2}$, Joachim G. J. V. Aerts ${ }^{1,2}$ and Heleen Vroman ${ }^{1,2 *}$ \\ ${ }^{1}$ Department of Pulmonary Medicine, Erasmus Medical Center, Rotterdam, Netherlands, ${ }^{2}$ Erasmus Cancer Institute, \\ Erasmus Medical Center, Rotterdam, Netherlands
}

OPEN ACCESS

Edited by:

Diana Dudziak,

Universitätsklinikum Erlangen,

Germany

Reviewed by:

Katsuaki Sato,

University of Miyazaki, Japan

Richard A. Kroczek,

Robert Koch Institute, Germany

${ }^{*}$ Correspondence:

Heleen Vroman

h.vroman@erasmusmc.nl

Specialty section:

This article was submitted to Antigen Presenting Cell Biology,

a section of the journal

Frontiers in Immunology

Received: 16 July 2018 Accepted: 14 November 2018 Published: 03 December 2018

Citation:

Huber A, Dammeijer F, Aerts JGJV and Vroman H (2018) Current State of Dendritic Cell-Based Immunotherapy:

Opportunities for in vitro Antigen

Loading of Different DC Subsets?

Front. Immunol. 9:2804.

doi: 10.3389/fimmu.2018.02804
Dendritic cell (DC) based cancer immunotherapy aims at the activation of the immune system, and in particular tumor-specific cytotoxic T lymphocytes (CTLs) to eradicate the tumor. DCs represent a heterogeneous cell population, including conventional DCs (cDCs), consisting of cDC1s, cDC2s, plasmacytoid DCs (pDCs), and monocyte-derived DCs (moDCs). These DC subsets differ both in ontogeny and functional properties, such as the capacity to induce $\mathrm{CD}^{+}{ }^{+}$and $\mathrm{CD} 8^{+} \mathrm{T}$-cell activation. MoDCs are most frequently used for vaccination purposes, based on technical aspects such as availability and in vitro expansion. However, whether moDCs are superior over other DC subsets in inducing anti-tumor immune responses, is unknown, and likely depends on tumor type and composition of the tumor microenvironment. In this review, we discuss cellular aspects essential for DC vaccination efficacy, and the most recent findings on different DC subsets that could be used for DC-based cancer immunotherapy. This can prove valuable for the future design of more effective DC vaccines by choosing different DC subsets, and sheds light on the working mechanism of DC immunotherapy.

Keywords: dendritic cell (DC), Immunotherapy, DC subsets, T cell responses, tumor immunology

\section{INTRODUCTION}

The immune system is able to distinguish between self, non-self and eliminate damaged cells. Consequently, it has the potential to eradicate cancerous cells displaying mutated, or aberrantly expressed self-antigens. To avoid elimination by immune responses, tumors not only acquire the ability to prevent immune recognition, but also create an immunosuppressive environment and actively hijack immune cells to aid in tumor progression $(1,2)$. Re-activating the immune system to treat patients with cancer was already proposed at the end of the nineteenth century and cancer immunotherapy has further developed ever since (3-6). One type of immunotherapy is dendritic cell (DC) vaccination (7). DC vaccination makes use of autologous DCs loaded ex-vivo with specific tumor-associated antigens (TAAs) or whole tumor lysate to generate an immune response aiming for cancer-cell elimination. DC vaccination using ex-vivo generated monocyte-derived DCs (moDCs) in patients with cancer was first explored over two decades ago (8). Numerous clinical trials [over 200 (9)] have established the safety and ability of moDC vaccines to induce anti-tumor responses (10-12). More recently, also in vivo loading of DCs is being exploited (13-17). In this review, we will discuss the cellular aspects essential for DC vaccination efficacy, the potential of distinct DC subsets as sources for DC vaccination, and the implications for the future design of DC vaccines. 


\section{DENDRITIC CELLS}

DCs play a crucial role in the immune system and link innate and adaptive immune responses (18-21). They arise from progenitor cells in the bone marrow and reside in peripheral tissues in an immature state. Immature DCs (iDCs) are specialized in antigen capturing, processing, and presentation. Upon appropriate stimulation mediated by inflammatory and pathogen-derived signals, iDCs undergo maturation. Mature DCs express co-stimulatory molecules, secrete cytokines, and migrate to lymphoid organs where they activate antigen-specific T-cells (22). Besides the presentation of exogenous antigens on MHC-II peptides, DCs are able to cross-present exogenously captured antigens on MHC I-associated peptides (23). Thereby, DCs can present TAAs to $\mathrm{CD}^{+}{ }^{+} \mathrm{T}$-cells which makes them of particular interest for cancer immunotherapy (24).

DCs consist of developmentally and functionally distinct DC subsets. These include moDCs, conventional DCs-consisting of cDC1s and $\mathrm{cDC} 2 \mathrm{~s}$ - and plasmacytoid DCs (pDCs) (2527). While moDCs are derived from the common monocyte progenitors (cMoPs), $\mathrm{cDCs}$, and $\mathrm{pDCs}$ arise from a common DC precursor (27-29). Each DC subset has specialized functions however, these are not exclusive and seem to depend on both location and environmental cues (30). In general, moDCs efficiently promote T-cell differentiation, but are poor inducers of $\mathrm{CD}^{+}$T-cell proliferation (31). In contrast, moDCs can be powerful activators of tumor-specific $\mathrm{CD}^{+}$T-cells (32). It is known that mature moDCs secrete chemokines and pro-inflammatory cytokines which are crucial to attract other immune cells and T-cells to the local environment (33). cDC1s are specialized in recognizing viral and intracellular antigens and are important for cytotoxic T-cell (CTL) responses, whereas cDC2s are particularly apt in priming $\mathrm{CD}^{+}{ }^{+} \mathrm{T}$-cells (34). Depending on the experimental model, cDC2s induce T-helper (Th) 2 or Th17 responses $(35,36)$. pDCs are prominent producers of type I interferon in response to single-stranded RNA and double-stranded DNA upon e.g., viral infections, which is important for DC maturation and $\mathrm{CD}^{+}$T-cell activation $(34,37)$. However, their antigen-presenting capacity is being questioned, especially as it was recently discovered that $\mathrm{pDC}$ characterized by $\mathrm{CD} 123$ expression and BDCA2 are contaminated by pre-cDCs $(38,39)$.

\section{VACCINES}

DC-based cancer immunotherapy depends on the crucial role that DCs play in inducing antigen-specific T-cell responses (40). In many tumors, immune responses are ineffective due to the immunosuppressive environment of the tumor and/or the lack of immunogenicity of the tumor $(41,42)$. In addition, the tumor microenvironment (TME) promotes exhaustion of effector $\mathrm{CD}^{+}$T-cells (43). Some tumors are even able to hamper the recruitment of $\mathrm{CDC} 1 \mathrm{~s}$, by downregulating CCL4 signaling upon constitutively active $\beta$-catenin signaling and thereby hamper priming and accumulation of tumor-infiltrating T-cells (44), indicating the importance of endogenous DCs for initiating antitumor immunity. DC vaccines aim to overcome the absence or malfunctioning of endogenous DCs by manipulating autologous DCs to enhance T-cell responses directed against the tumor.

Currently a wide range of procedures to generate autologous DCs exist using distinct sources, such as peripheral blood monocytes, naturally occuring DCs, or $\mathrm{CD} 34^{+}$hematopoietic precursor cells mobilized from the bone marrow (10), enabling the generations of various DC subsets [such as moDCs, cDCs, or pDCs (45-47)]. In addition, different sources of TAAs [e.g., cancer cell line lysate, whole tumor lysate, or tumorassociated peptides $(45,48,49)]$, as well as different antigenloading methods [such as pulsing, via viral vectors, or mRNA transfection (10)] are used to load DCs. Moreover, various maturation methods including cytokines, CD40 ligands, and TLR agonists (50) are known. Currently, there is a great effort made in improving existing DC vaccines and developing new ones. New approaches include genetically engineered DCs that express TAAs or display enhanced immunostimulatory properties or explore in vivo antigen loading of DCs with freshly released TAAs due to chemotherapy or immunogenic tumor-cell death (51-58).

\section{GENERATION OF PATIENT-DERIVED DCs EX VIVO}

Because DCs comprise $<1 \%$ of peripheral blood mononuclear cells (PBMCs), one major challenge is the generation of sufficient numbers of DCs for vaccination purposes. Therefore, DC vaccination studies frequently used moDCs that can be generated ex-vivo in large numbers from purified monocytes that were consequently cultured with granulocyte-macrophage colony-stimulating factor (GM-CSF) and interleukin (IL)-4 (59). Recently, it was described that monocytes cultured with GMCSF and IL-6, and activated with IFN- $\gamma$, give rise to a newly described mo-cDC1s population that has similarities to $\mathrm{CDC} 1 \mathrm{~s}$ (60). In addition, cDCs and pDCs can be generated from CD34 $4^{+}$ hematopoietic stem cells using fms-like tyrosine kinase 3 ligand (Flt3L) (61, 62).

The phenotype, function and ability to induce T-cell responses by in vitro generated DCs is highly dependent on the culture methods used (63). For instance, culturing human monocytes with $\mathrm{CD} 137$ protein generates DCs potent in inducing $\mathrm{CD} 8^{+}$ T-cells with superior lysing capabilities against cells infected with cancer-causing viruses $(64,65)$. Comparing different technologies for monocyte isolation demonstrated that isolation techniques can also influence the antitumor immunogenicity and cytokine production of the generated moDCs $(66,67)$. Furthermore, the cytokines and growth factors required for precursor-cell differentiation into DCs and subsequent activation influence DC function, and in consequence, the effectivity of DC vaccines (68-71).

\section{LYMPH NODE HOMING OF VACCINATED DCs}

To activate antigen-specific T-cell responses, DCs need to reach the lymph nodes (LNs) in order to present antigen to cognate TAA-specific T-cells. In order to optimize DC-trafficking 
to the LN, various injection routes and strategies have been explored. In a pre-clinical mouse study, different vaccination routes were compared to load DCs in vivo with naked antigenencoded RNA. Herein it was shown that only intra-nodal (i.n) vaccination induced potent expansion of antigen-specific $\mathrm{T}$ cells resulting in prolonged survival, which was not observed upon intra-dermal (i.d.), subcutaneous, or near nodal vaccination (72), indicating the superiority of i.n. vaccination. However, in various clinical studies superior efficacy of i.n. vaccination was less clear. In one study, moDCs pulsed with three melanoma peptides were administered either i.d. or i.n. to 25 patients with metastatic melanoma. After i.d. administration, $4 \%$ of DCs migrated to the LNs, whereas migration upon i.n. injection varied between 0 and $56 \%$. The total number of vaccinated moDCs in single LNs were 10- to 30-fold higher after i.n. administration than i.d. injection. However, surprisingly, there was no difference in the strength of the immune response evaluated by TAA-specific $\mathrm{CD}^{+}$T-cells isolated from DTH reactions between the two administration routes (73). Another study in 54 patients with different types of HER2 ${ }^{+}$breast cancer employed moDCs loaded with six HER2 MHC class II binding peptides injected intralesionally, i.n. or both. More than $80 \%$ of the patients had new or increased systemic antiHER $2 \mathrm{CD}^{+}{ }^{+}$or $\mathrm{CD}^{+}{ }^{+}$T-cell responses and 32 patients had a HER2-specific $\mathrm{CD}^{+}{ }^{+} \mathrm{T}$-cell response in the sentinel $\mathrm{LN}$ (SLN) after vaccination but these were not significantly different between the three administration routes (74). The large variation observed upon i.n. vaccination also stress the difficulty of i.n. vaccination over i.d. vaccination, and could indicate that accurate i.n. vaccination outperforms i.d. vaccination. It has also been shown that migration to the LNs upon i.d. vaccination can be improved by pre-treating the vaccination site with a potent recall antigen, as tetanus/diphtheria (Td) toxoid pretreatment. This improved DC migration to the LNs, progression free survival and overall survival in patients with glioblastoma (75). Strikingly, systemic TAA-specific immune responses and enhanced tumor CD8 ${ }^{+}$T-cell infiltration were even observed upon intra-tumoral injection of DCs containing an vector expressing the CCL21 gene in 16 patients with advanced non-small cell lung carcinoma (NSCLC) (54).

Therefore, the superior route or site of injection is still unknown, as no differences were found in safety or antigenspecific immune responses upon either intradermal or -nodal injection $(73,74)$. These results further urge the need to compare DC vaccination efficacy between different administration routes.

\section{EVALUATION OF EFFICACY OF EX VIVO GENERATED MODC VACCINES}

As the molecular underpinnings of an effective DC-therapy induced T-cell response are still incompletely understood, it has been difficult to identify factors associated with therapeutic success. As the location and mechanism of T-cell immune responses initiated upon DC therapy is unknown, there is also no consensus how DC vaccination efficacy should be evaluated. One effort to generalize the monitoring of effectivity is by the Response Evaluation Criteria in Solid Tumors (RECIST) or by the more recently described modified RECIST, which enables categorization of patient responses into complete response, partial response, stable disease and progressive disease determined by the amount of tumor shrinkage of a given number of tumor lesions, disease progression, and assessment of pathological LNs $(76,77)$. Nevertheless, various studies monitored response differently and focused on either clinical responses (summarized in Table 1) or different aspects of the immune response. Moreover, most studies failed to find significant correlations of measured immune characteristics and clinical outcome.

A phase I clinical trial employed autologous tumor lysatepulsed moDCs in ten patients with malignant mesothelioma after chemotherapy. Clinical responses were evaluated by modified RECIST. In addition, efficacy of DC vaccination was determined by increased cytotoxicity of isolated PBMCs against tumor cells and higher percentages of $\mathrm{CD}^{+} \mathrm{T}$-cells expressing granzyme $\mathrm{B}$, an indication for their capacity to lyse cells. After vaccination, four out of six patients showed increased cytotoxicity levels and granzyme $\mathrm{B}$ expressing $\mathrm{CD}^{+}$T-cells increased in nine patients (45). In another phase I clinical trial in nine patients with mesothelioma using allogeneic tumor cell lysate-pulsed moDCs, tumor-specific T-cells could be detected in the majority of patients in a skin biopsy after a positive DTH skin test. In addition, radiographic responses (two partial responses and seven patients with stable disease), progression free survival (8.8 months) and overall survival [(OS) not reached] of the patients were monitored and analyzed according to modified RECIST criteria (78). During one study in 27 prostate cancer patients with rising serum prostate-specific antigen [(PSA); indication for biochemical relapse of prostate cancer] levels, kinetics of PSA was monitored and used to determine the efficacy of the vaccination with moDC pulsed with allogeneic tumor cell lysate. The median PSA doubling time (PSADT), which determines clinical outcome, increased from 5.67 to 18.85 months. In addition, the frequency of PSA-specific T-cells increased after vaccination and tumor-specific IgG antibodies could be detected in nine patients. However, these immune response characteristics did not significantly correlate with PSADT (48). A recent phase I clinical trial in patients with NSCLC employed moDCs pulsed with two TAAs, silenced with SOCS1, and stimulated with flagellin. Upon vaccination, regulatory T-cells (Tregs) decreased, and three patients had increased levels of IL- 6 and/or TNF $\alpha$, whereas IL-2, IL-4, IL-10, and IFN $\gamma$ were unaffected. These observed immune responses did not correlate with the clinical response (49). Another phase II trial in 156 patients with hepatocellular carcinoma (no residual tumor after standard treatment) investigated DC-based adjuvant immunotherapy using triple TAA-pulsed moDCs. While recurrence-free survival (RFS) and OS were not different between the immunotherapy and control (no treatment) groups, immunotherapy increased TAA-reactive T-cell responses and IFN $\gamma$ levels, whereas levels of serum TGF- $\beta$ decreased. Nevertheless, this did not correlate to RFS. Interestingly, when radiofrequency ablation (RFA) patients were excluded in post-hoc analyses, immunotherapy did prolong RFS of non-RFA patients (79). 
TABLE 1 | Clinical trials employing different DC subsets and different sources of antigens.

\begin{tabular}{|c|c|c|c|c|c|c|}
\hline $\begin{array}{l}\text { DC } \\
\text { subset }\end{array}$ & $\begin{array}{l}\text { Loading } \\
\text { with }\end{array}$ & $\begin{array}{l}\text { No. of } \\
\text { patients }\end{array}$ & Tumor type & Vaccination procedure & Clinical outcome & References \\
\hline moDC & $\begin{array}{l}\text { Autologous } \\
\text { lysate }\end{array}$ & 10 & $\begin{array}{l}\text { Epithelial } \\
\text { MPM }\end{array}$ & $\begin{array}{l}\text { Three vaccinations i.d. (1/3) and i.v. } \\
(2 / 3) \text { in at } 0,2 \text { and } 4 \text { weeks }\end{array}$ & $\begin{array}{l}\text { CT scans and chest X-rays analyzed } \\
\text { with modified RECIST: PRs }(n=3) \text {, } \\
\text { SD }(n=1) \text { and NR }(n=6)\end{array}$ & $(45)$ \\
\hline moDC & $\begin{array}{l}\text { Allogeneic } \\
\text { tumor cell } \\
\text { lysate }\end{array}$ & 9 & MPM & $\begin{array}{l}\text { Three biweekly vaccinations i.d. (1/3) } \\
\text { and i.v. (2/3), followed by a boost at } 3 \\
\text { and } 6 \text { months }\end{array}$ & $\begin{array}{l}\text { CT scans analyzed with modified } \\
\text { RECIST: PR }(n=2), \text { SD }(n=7) \\
\text { Median PFS of } 8.8 \text { months and } \\
\text { median OS not reached }\end{array}$ & (78) \\
\hline moDC & $\begin{array}{l}\text { Allogeneic } \\
\text { tumor cell } \\
\text { lysate }\end{array}$ & 27 & $\begin{array}{l}\text { Prostate } \\
\text { cancer }\end{array}$ & $\begin{array}{l}\text { Twelve vaccinations s.c. at the axillary } \\
\text { and inguinal areas; patients received } \\
1 \text { week of cyclophosphamide in } \\
\text { metronomic setting prior to } \\
\text { vaccinations }\end{array}$ & $\begin{array}{l}\text { Increase of median PSADT from } 5.67 \\
\text { (prior treatment) to } 18.85 \text { months } \\
\text { (after treatment) }\end{array}$ & $(48)$ \\
\hline moDC & 2 TAAs & 15 & NSCLC & $\begin{array}{l}\text { Three vaccinations i.v. in 1-week } \\
\text { intervals }\end{array}$ & $\begin{array}{l}\text { Long-term follow-up until 2017: low } \\
\text { dose group: no recurrence, } \\
\text { progressive disease and death ( } n=1 \\
\text { each); middle dose group: no } \\
\text { recurrence }(n=3) \text {; high dose group: } \\
\text { no recurrence }(n=7) \text {, progressive } \\
\text { disease and death }(n=1)\end{array}$ & (49) \\
\hline moDC & 3 TAAs & 156 & $\begin{array}{l}\text { Hepatocellular } \\
\text { carcinoma }\end{array}$ & $\begin{array}{l}\text { Six injections s.c. near the inguinal } \\
\text { lymph nodes over } 14 \text { weeks }\end{array}$ & $\begin{array}{l}\text { Difference in RFS not statistically } \\
\text { significant between treated and } \\
\text { control groups; Significantly } \\
\text { prolonged RFS in the treated } \\
\text { non-radiofrequency ablation } \\
\text { subgroup }\end{array}$ & (79) \\
\hline moDC & TAA-mRNA & 30 & $\begin{array}{l}\text { AML (in } \\
\text { remission) }\end{array}$ & $\begin{array}{l}\text { I.d. injections four times at 2-week } \\
\text { intervals }\end{array}$ & $\begin{array}{l}\text { Antileukemic effect }(n=13) \text { with } \\
\text { minimal residual disease }(n=9) \text { or SD } \\
(n=4) \text {; significantly higher OS and } \\
\text { RFS compared to non-responders }\end{array}$ & (80) \\
\hline moDC & $\begin{array}{l}4 \text { HLA class I } \\
\text { and } 6 \text { HLA } \\
\text { class II } \\
\text { peptides }\end{array}$ & 53 & $\begin{array}{l}\text { Metastatic } \\
\text { melanoma }\end{array}$ & $\begin{array}{l}\text { Four vaccinations (at week 0, 2, } 6 \text {, } \\
\text { 10) followed after } 2 \text { months by } 6 \\
\text { vaccination maintenance cycles for } \\
\text { up to } 2 \text { years }\end{array}$ & $\begin{array}{l}\text { No regression of all metastases } \\
\text { according to WHO criteria but slow } \\
\text { regression of individual metastases; } \\
75 \% \text { OS at } 5 \text { years in group of } \\
\text { tumor-free patients; } 19 \% \text { of patients } \\
\text { still alive after } 12 \text {-year follow-up }\end{array}$ & (81) \\
\hline moDC & $\begin{array}{l}6 \text { HER2 MHC } \\
\text { class II } \\
\text { binding } \\
\text { peptides }\end{array}$ & 42 & $\begin{array}{l}\mathrm{HER} 2^{+} \\
\text {breast cancer }\end{array}$ & $\begin{array}{l}\text { Six weekly injections into the breast, } \\
\text { into the groin LNs, or into both breast } \\
\text { and in groin LNs }\end{array}$ & $\begin{array}{l}\text { Higher pathologic complete response } \\
\text { rate in ductal carcinoma in situ } \\
\text { patients compared with invasive } \\
\text { breast cancer patients ( } 28.6 \% \text { vs. } \\
8.3 \% \text { ) }\end{array}$ & $(74)$ \\
\hline cDC2s & 3 TAAs & 14 & $\begin{array}{l}\text { Metastatic } \\
\text { melanoma }\end{array}$ & $\begin{array}{l}\text { Three i.n. injections once every } 2 \\
\text { weeks; followed by } 2 \text { maintenance } \\
\text { cycles of } 3 \text { biweekly vaccinations } \\
\text { each with a } 6 \text {-week interval }\end{array}$ & $\begin{array}{l}\text { Long-term PFS of } 12-35 \text { months ( } n= \\
\text { 4) and median OS of } 13.3 \text { months }\end{array}$ & $(47)$ \\
\hline pDCs & 3 TAAs & 15 & $\begin{array}{l}\text { Metastatic } \\
\text { melanoma }\end{array}$ & $\begin{array}{l}\text { Three i.n. injections once every } 2 \\
\text { weeks, followed by } 2 \text { maintenance } \\
\text { cycles of } 3 \text { biweekly vaccinations with } \\
\text { a } 6 \text {-week interval }\end{array}$ & $\begin{array}{l}\text { SD }(n=2) \text {, mixed response }(n=1) \text {; } \\
\text { increased PFS ( } 4.0 \text { vs. } 2.1 \text { months) } \\
\text { and OS ( } 22.0 \text { vs. } 7.6 \text { months) } \\
\text { compared to } 72 \text { matched control } \\
\text { (chemotherapy-treated) patients }\end{array}$ & $(46)$ \\
\hline
\end{tabular}

AML, acute myeloid leukemia; cDC2s, conventional DCs 2; CT, computed tomography; i.d, intra-dermal; i.n., intra-nodal; i.v., intra-venously; moDCs, monocyte-derived DCs; MPM, malignant pleural mesothelioma; NR, no response; NSCLC, non-small cell lung carcinoma; PR, partial response; RECIST, Response Evaluation Criteria in Solid Tumors; OS, overall survival; pDCs, plasmacytoid DCs; PFS, progression-free survival; PSADT, prostate-specific antigen doubling time; RFS, recurrence-free survival; SD, stable disease; TAA, tumor-associated antigen; s.c. subcutaneous.

In contrast, a phase II study in 30 patients with acute myeloid leukemia could correlate long-term OS with higher numbers of circulating TAA-specific CD8 ${ }^{+}$T-cells after therapy with moDCs electroporated with TAA-mRNA (80). Furthermore, a phase I/II clinical trial that studied the effectivity of DC vaccination in 62 patients with melanoma used moDCs loaded with 4 HLA class I peptides and 6 HLA class II peptides. DC vaccination increased the numbers of vaccines-specific 


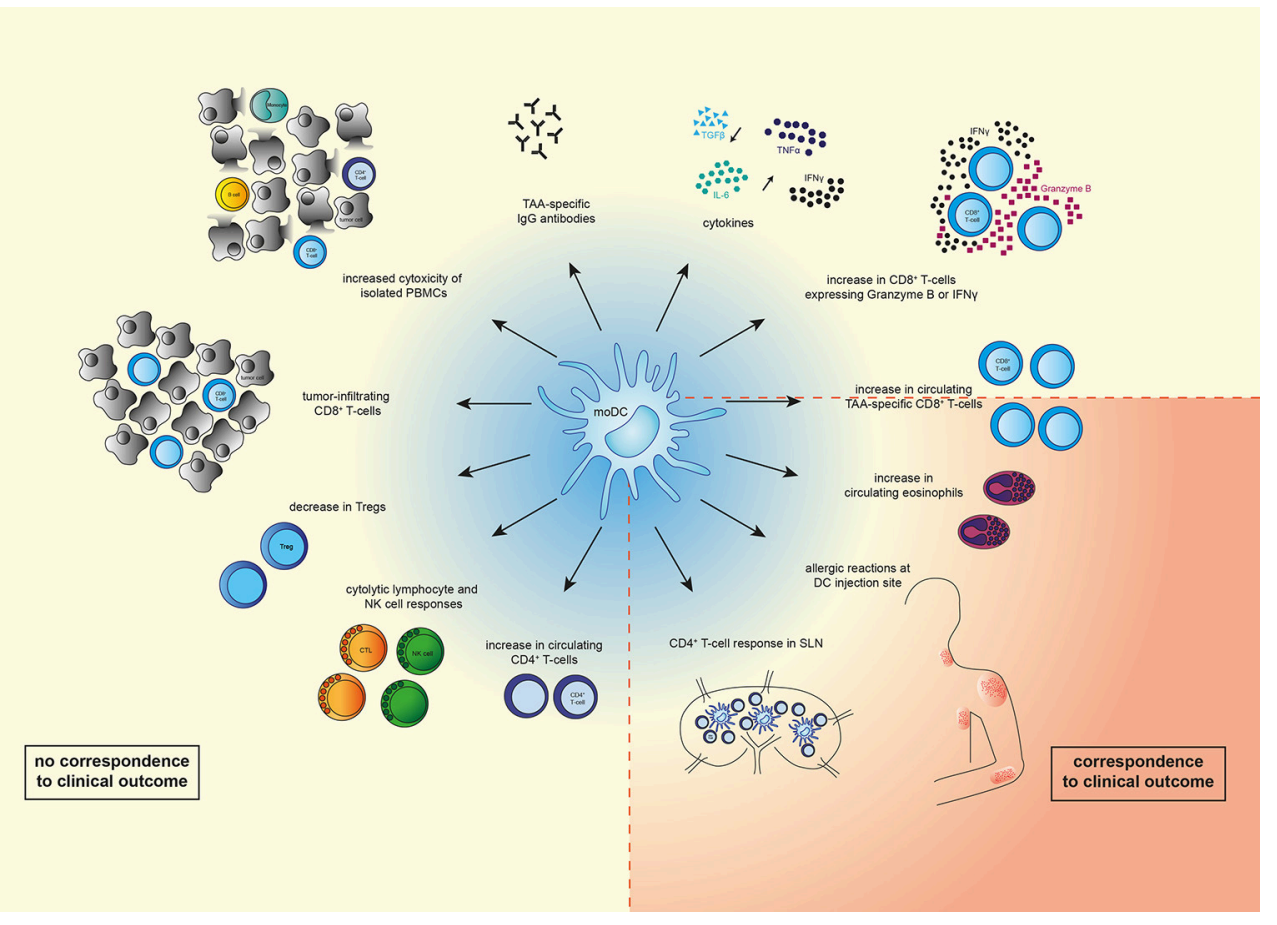

FIGURE 1 | Overview of immunological changes observed upon moDC therapy. Vaccination with moDCs can lead to various immunological changes such as an increase in numbers of circulating immune cells (TAA-specific CD8 ${ }^{+}$T-cells, CD8 ${ }^{+}$T-cells expressing IFN $\gamma$ or Granzyme B, CD4 ${ }^{+}$T-cells, eosinophils), or a decrease of other immune cells (Tregs). In addition, systemic cytolytic lymphocyte (CTL) or natural killer (NK) cell responses, as well as CD4+ $4^{+}$-cell responses in sentinel lymph nodes (LNs) were observed. Levels of TAA-specific IgG antibodies and cytokines (IL-6, IFN $\gamma$, TNF $\alpha$ ) increased, whereas levels of TGF $\beta$ decreased. Vaccination with moDCs also resulted in tumor-infiltrating CD8 ${ }^{+}$T-cells, increased cytotoxicity of isolated PBMCs (monocytes, $\mathrm{CD}^{+}$and $\mathrm{CD} 4^{+} \mathrm{T}$-cells, $\mathrm{B}$-cells), and allergic reactions at the DC injection site. Of the shown changes, only increased circulating TAA-specific CD8 ${ }^{+}$T-cells, eosinophilic blood count, strength of allergic reactions at DC injection site, and a CD4+ T-cell response in sentinel LNs correspond to clinical outcome.

IFN $\gamma$-producing T-cells, whereas numbers of Tregs and myeloid derived suppressor cells (MDSCs) were unaltered. Surprisingly, IFN $\gamma$-producing T-cells did not correlate with OS, whereas the intensity of allergic vaccine-injection site reactions significantly correlated with OS. Furthermore, a maximal eosinophilic blood count (>250 per $100 \mu \mathrm{l}$ blood) significantly improved survival specifically in tumor bearing melanoma patients (81). Another study in 42 patients with HER $2^{+}$breast cancer, that used moDCs pulsed with six HER2 MHC class II binding peptides, could correlate pathologic complete response with the $\mathrm{CD} 4^{+}$Th1 immune response in the sentinel LN, but in peripheral blood (74).

Overall, it seems that DC vaccination induced various immune responses, but most of the observed immunological responses do not reflect clinical responses (Figure 1). This could be due to the fact that most studies are phase I/II clinical trials in which safety and feasibility are the primary outcomes and not efficacy. Furthermore, this could be caused by the type and location of the immune response measured, as most studies focused on TAA-specific T-cells in peripheral blood. As DC vaccination initiates T-cell responses in the LNs and these TAA-specific T-cells exert their cytolytic function in the tumor, it would be more likely that immune responses in LNs or in the tumor predict OS better than immune responses measured in peripheral blood. This could be performed using a recently described method that can quantify tumor-specific CTLs in preclinical models at different sites (82).

Furthermore, it was shown in murine models that $\mathrm{DC}$ vaccines elicited cytotoxic and regulatory natural killer cell responses against tumors $(83,84)$. This stresses the necessity to investigate other cell subsets, besides T-cells, influenced by DC vaccines.

\section{POTENTIAL OF NATURALLY OCCURRING DC SUBSETS FOR USE AS VACCINES}

Despite the growing knowledge in DC immunobiology, the exact diversity and biology of T-cell responses generated by different DC vaccines is still poorly understood. The recent development of antibody-coated magnetic beads enables the isolation of natural occurring DC subsets directly from peripheral blood in considerate numbers. For example, more than 10 million pDCs or more than 27 million cDCs can be isolated from apheresis products $(46,47)$.

The first phase I/II clinical trials have been performed using naturally occurring DCs for DC therapy and have shown that this is safe and feasible $(46,85)$. One of the clinical trials that used naturally occurring cDC2s loaded with three TAAs 
in 14 melanoma patients showed that the presence of TAAspecific T-cells in peripheral blood and DTH tests correlated with progression-free survival in three patients (47). Another clinical study in 15 patients with metastatic melanoma used pDCs pulsed with three TAAs. Increased TAA-specific $\mathrm{CD}^{+}$T-cell frequencies were measured in the blood of seven of the fifteen patients. Clinical outcome (PFS and OS) of patients treated with TAA-loaded pDCs was increased as compared to 72 matched control patients treated with chemotherapy (46).

Unfortunately, it is unknown whether naturally occurring DCs outperform cultured moDCs as source for DC therapy in patients, as clinical trials comparing different DC subsets as a source for DC therapy have not been performed. However, in mice, efficacy of different DC subsets for DC-therapy was compared. Herein, they found that moDCs in the tumor are superior in antigen uptake and processing but failed to induce efficient T-cell proliferation. MoDCs in the tumor even seemed to have immunosuppressive properties, as they inhibited T-cell proliferation by increased iNOS expression (86), however this is likely dependent on environmental cues, as cultured moDCs are highly immunogenic. Tumoral $\mathrm{cDC} 1 \mathrm{~s}$ were superior in stimulating naïve and previously activated CD8 ${ }^{+}$ T-cells, beneficial for tumors with abundant Tregs, whereas cDC2s purified from tumor were more efficient in $\mathrm{CD}^{+}$ T-cell stimulation and differentiation into Th17 cells, which was effective for tumors with abundant M2-oriented tumorpromoting tumor-associated macrophages (TAMs) $(86,87)$. In another study of melanoma mouse models, $\mathrm{cDC} 1 \mathrm{~s}$ but not $\mathrm{cDC} 2 \mathrm{~s}$ were shown to transport intact TAAs to TdLNs and cross-present them to $\mathrm{CD}^{+}$T-cells (88). Whether these findings will be confirmed with ex vivo loading of natural occurring DCs remains to be determined, and is currently extensively studied.

\section{IMPLICATIONS FOR FUTURE DESIGN OF DENDRITIC CELL VACCINES}

The use of different natural occurring DC subsets for vaccination is promising and more studies directly comparing the various

\section{REFERENCES}

1. Schreiber RD, Old LJ, Smyth MJ. Cancer immunoediting: integrating immunity's roles in cancer suppression and promotion. Science (2011) 331:1565-70. doi: 10.1126/science.1203486

2. Zou W. Immunosuppressive networks in the tumour environment and their therapeutic relevance. Nat Rev Cancer (2005) 5:263. doi: 10.1038/nr c1586

3. Coley WB. The treatment of malignant tumors by inoculations of erysipelas. $J$ Am Med Assoc. (1893) 615-6.

4. Ehrlich P. Ueber den jetzigen Stand der Karzinomforschung. Ned Tijdschr Geneeskd. (1909) 5:273-90.

5. Burnet FM. The concept of immunological surveillance. Prog Exp Tumor Res. (1970) 13:1-27. doi: 10.1159/000386035

6. Muul LM, Spiess PJ, Director EP, Rosenberg SA. Identification of specific cytolytic immune responses against autologous tumor in humans bearing malignant melanoma. J Immunol. (1987) 138: 989-95. subsets are urgently needed. In addition, more research into the contribution of the DC subsets to the different aspects of antitumor immunity is required, as this can be beneficial for tumors with different composition of the TME.

It is known that different types of human solid tumors are infiltrated to various extents by different types of immune cells (89-91). The presence of these immune infiltrates even has prognostic value (92-94). Moreover, it might guide the choice of which DC type to employ for vaccination, as different DC subsets elicit differing T-cell responses against the tumor. Hence, identifying whether the immunosuppressive environment of the tumor consists Tregs or TAMs before treatment might help in choosing the right $\mathrm{DC}$ subset to induce the proper $\mathrm{T}$-cell skewing.

Besides the direct (re)activation of tumor-specific Tcells, efforts are undertaken to combine DC vaccination with agents that can modulate the TME itself e.g., by immunotherapy, radiotherapy, or chemotherapy to act synergistically with DC vaccination, which can improve immunogenicity, T-cell infiltration, T-cell exhaustion, and overcome the immunosuppressive environment of the tumor (82, 95-98).

\section{CONCLUSION REMARKS}

Although DC vaccination has been optimized in recent years, a great potential for improvement still remains. More (pre)clinical studies investigating the working mechanisms underlying DC vaccine efficacy are required. Therein, a major focus should be laid on different DC (and other myeloid) subpopulations and their specialized contribution to antitumor immunity, as it is likely that different cancer types might need different DC therapeutic strategies.

\section{AUTHOR CONTRIBUTIONS}

All authors listed have made a substantial, direct and intellectual contribution to the work, and approved it for publication.
7. Steinman RM. Decisions about dendritic cells: past, present, and future. Annu Rev Immunol. (2012) 30:1-22. doi: 10.1146/annurev-immunol-100311-102839

8. Hsu FJ, Benike C, Fagnoni F, Liles TM, Czerwinski D, Taidi B, et al. Vaccination of patients with B-cell lymphoma using autologous antigen-pulsed dendritic cells. Nat Med. (1996) 2:52. doi: 10.1038/nm0196-52

9. Ahmed MS, Bae Y-S. Dendritic cell-based therapeutic cancer vaccines: past, present and future. Clin Exp Vaccine Res. (2014) 3:113-6. doi: 10.7774/cevr.2014.3.2.113

10. Constantino J, Gomes C, Falcão A, Neves BM, Cruz MT. Dendritic cell-based immunotherapy: a basic review and recent advances. Immunol Res. (2017) 65:798-810. doi: 10.1007/s12026-017-8931-1

11. Bol KF, Schreibelt G, Gerritsen WR, de Vries IJM, Figdor CG. Dendritic cellbased immunotherapy: state of the art and beyond. Clin Cancer Res. (2016) 22:1897-906. doi: 10.1158/1078-0432.CCR-15-1399

12. Garg AD, Coulie PG, Van den Eynde BJ, Agostinis P. Integrating nextgeneration dendritic cell vaccines into the current cancer immunotherapy landscape. Trends Immunol. (2017) 38:577-93. doi: 10.1016/j.it.2017.05.006 
13. Tacken PJ, de Vries IJM, Torensma R, Figdor CG. Dendritic-cell immunotherapy: from ex vivo loading to in vivo targeting. Nat Rev Immunol. (2007) 7:790. doi: 10.1038/nri2173

14. Tacken PJ, Figdor CG. Targeted antigen delivery and activation of dendritic cells in vivo: Steps towards cost effective vaccines. Semin Immunol. (2011) 23:12-20. doi: 10.1016/j.smim.2011.01.001

15. Tacken PJ, de Vries IJM, Gijzen K, Joosten B, Wu D, Rother RP, et al. Effective induction of naive and recall $\mathrm{T}$-cell responses by targeting antigen to human dendritic cells via a humanized anti-DC-SIGN antibody. Blood (2005) 106:1278-85. doi: 10.1182/blood-2005-01-0318

16. Dhodapkar MV, Sznol M, Zhao B, Wang D, Carvajal RD, Keohan ML, et al. Induction of antigen-specific immunity with a vaccine targeting NY-ESO-1 to the dendritic cell receptor DEC-205. Sci Trans Med. (2014) 6:232ra251232ra251. doi: 10.1126/scitranslmed.3008068

17. Altin JG, van Broekhoven CL, Parish CR. Targeting dendritic cells with antigen-containing liposomes: antitumour immunity. Expert Opin Biol Ther. (2004) 4:1735-47. doi: 10.1517/14712598.4.11.1735

18. Guéry JC, Adorini L. Dendritic cells are the most efficient in presenting endogenous naturally processed self-epitopes to class II-restricted T cells. J Immunol. (1995) 154:536-44.

19. Banchereau J, Steinman RM. Dendritic cells and the control of immunity. Nature (1998) 392:245. doi: 10.1038/32588

20. Mellman I, Steinman RM. Dendritic cells. Cell (2001) 106:255-8. doi: 10.1016/S0092-8674(01)00449-4

21. Banchereau J, Palucka AK. Dendritic cells as therapeutic vaccines against cancer. Nat Rev Immunol. (2005) 5:296. doi: 10.1038/nri1592

22. Steinman RM. The dendritic cell system and its role in immunogenicity. Annu Rev Immunol. (1991) 9:271-96. doi: 10.1146/annurev.iy.09.040191.001415

23. Heath WR, Carbone FR. Cross-presentation, dendritic cells, tolerance and immunity. Annu Rev Immunol. (2001) 19:47-64. doi: 10.1146/annurev.immunol.19.1.47

24. Huang A, Golumbek P, Ahmadzadeh M, Jaffee E, Pardoll D, Levitsky H. Role of bone marrow-derived cells in presenting MHC class I-restricted tumor antigens. Science (1994) 264:961-5. doi: 10.1126/science.7513904

25. Guilliams M, Henri S, Tamoutounour S, Ardouin L, Schwartz-Cornil I, Dalod $\mathrm{M}$, et al. From skin dendritic cells to a simplified classification of human and mouse dendritic cell subsets. Eur J Immunol. (2010) 40:2089-94. doi: 10.1002/eji.201040498

26. Heath WR, Carbone FR. Dendritic cell subsets in primary and secondary T cell responses at body surfaces. Nat Immunol. (2009) 10:1237. doi: 10.1038/ni.1822

27. Guilliams M, Ginhoux F, Jakubzick C, Naik SH, Onai N, Schraml BU, et al. Dendritic cells, monocytes and macrophages: a unified nomenclature based on ontogeny. Nat Rev Immunol. (2014) 14:571. doi: 10.1038/nri3712

28. Hettinger J, Richards DM, Hansson J, Barra MM, Joschko A-C, Krijgsveld J, et al. Origin of monocytes and macrophages in a committed progenitor. Nat Immunol. (2013) 14:821. doi: 10.1038/ni.2638

29. Naik SH, Sathe P, Park H-Y, Metcalf D, Proietto AI, Dakic A, et al. Development of plasmacytoid and conventional dendritic cell subtypes from single precursor cells derived in vitro and in vivo. Nat Immunol. (2007) 8:1217. doi: $10.1038 /$ ni1522

30. Ma Y, Shurin GV, Gutkin DW, Shurin MR. Tumor associated regulatory dendritic cells. Semin Cancer Biol. (2012) 22:298-306. doi: 10.1016/j.semcancer.2012.02.010

31. Chow KV, Lew AM, Sutherland RM, Zhan Y. Monocyte-derived dendritic cells promote Th polarization, whereas conventional dendritic cells promote Th proliferation. J Immunol. (2016) 196:624-36. doi: 10.4049/jimmunol.1501202

32. Kuhn S, Yang J, Ronchese F. Monocyte-derived dendritic cells are essential for CD8(+) T cell activation and antitumor responses after local immunotherapy. Front Immunol. (2015) 6:584. doi: 10.3389/fimmu.2015.00584

33. O'Neill DW, Adams S, Bhardwaj N. Manipulating dendritic cell biology for the active immunotherapy of cancer. Blood (2004) 104:2235-46. doi: 10.1182/blood-2003-12-4392

34. Collin M, Bigley V. Human dendritic cell subsets: an update. Immunology (2018) 154:3-20. doi: 10.1111/imm.12888

35. Gao Y, Nish SA, Jiang R, Hou L, Licona-Limón P, Weinstein JS, et al. Control of T helper 2 responses by transcription factor IRF4-dependent dendritic cells. Immunity (2013) 39:722-32. doi: 10.1016/j.immuni.2013.08.028
36. Schlitzer A, McGovern N, Teo P, Zelante T, Atarashi K, Low D, et al. IRF4 transcription factor-dependent CD11b(+) dendritic cells in human and mouse control mucosal IL-17 cytokine responses. Immunity (2013) 38:97083. doi: 10.1016/j.immuni.2013.04.011

37. Zitvogel L, Galluzzi L, Kepp O, Smyth MJ, Kroemer G. Type I interferons in anticancer immunity. Nat Rev Immunol. (2015) 15:405. doi: 10.1038/nri3845

38. Alcántara-Hernández M, Leylek R, Wagar LE, Engleman EG, Keler T, Marinkovich MP, et al. High-dimensional phenotypic mapping of human dendritic cells reveals interindividual variation and tissue specialization. Immunity (2017) 47:1037-50.e1036. doi: 10.1016/j.immuni.2017.11.001

39. See P, Dutertre C-A, Chen J, Günther P, McGovern N, Irac SE, et al. Mapping the human DC lineage through the integration of high-dimensional techniques. Science (2017) 356:eaag3009. doi: 10.1126/science.aag3009

40. Sallusto F, Lanzavecchia A. The instructive role of dendritic cells on T-cell responses. Arthritis Res. (2002) 4:S127-S132. doi: 10.1186/ar567

41. Ghirelli C, Hagemann T. Targeting immunosuppression for cancer therapy. J Clin Invest. (2013) 123:2355-7. doi: 10.1172/JCI69999

42. Blankenstein T, Coulie PG, Gilboa E, Jaffee EM. The determinants of tumour immunogenicity. Nat Rev Cancer (2012) 12:307. doi: 10.1038/nrc3246

43. Davoodzadeh Gholami M, kardar GA, Saeedi Y, Heydari S, Garssen J, Falak R. Exhaustion of $\mathrm{T}$ lymphocytes in the tumor microenvironment: Significance and effective mechanisms. Cell. Immunol. (2017) 322:1-14. doi: 10.1016/j.cellimm.2017.10.002

44. Spranger S, Bao R, Gajewski TF. Melanoma-intrinsic $\beta$-catenin signalling prevents anti-tumour immunity. Nature (2015) 523:231. doi: $10.1038 /$ nature 14404

45. Hegmans JP, Veltman JD, Lambers ME, Vries IJM, d Figdor CG, et al. Consolidative dendritic cell-based immunotherapy elicits cytotoxicity against malignant mesothelioma. Am J Respir Crit Care Med. (2010) 181:1383-90. doi: 10.1164/rccm.200909-1465OC

46. Tel J, Aarntzen EHJG, Baba T, Schreibelt G, Schulte BM, Benitez-Ribas D, et al. Natural human plasmacytoid dendritic cells induce antigen-specific T-cell responses in melanoma patients. Cancer Res. (2013) 73:1063-75. doi: 10.1158/0008-5472.CAN-12-2583

47. Schreibelt G, Bol KF, Westdorp H, Wimmers F, Aarntzen EHJG, Duivemande Boer T, et al. Effective clinical responses in metastatic melanoma patients after vaccination with primary myeloid dendritic cells. Clin Cancer Res. (2016) 22:2155-66. doi: 10.1158/1078-0432.CCR-15-2205

48. Fucikova J, Podrazil M, Jarolim L, Bilkova P, Hensler M, Becht E, et al. Phase I/II trial of dendritic cell-based active cellular immunotherapy with DCVAC/PCa in patients with rising PSA after primary prostatectomy or salvage radiotherapy for the treatment of prostate cancer. Cancer Immunol Immunother. (2018) 67:89-100. doi: 10.1007/s00262-017-2 068-X

49. Ge C, Li R, Song H, Geng $\mathrm{T}$, Yang J, Tan Q, et al. Phase I clinical trial of a novel autologous modified-DC vaccine in patients with resected NSCLC. BMC Cancer (2017) 17:884. doi: 10.1186/s12885-017-3 859-3

50. Nicolette CA, Healey D, Tcherepanova I, Whelton P, Monesmith T, Coombs L, et al. Dendritic cells for active immunotherapy: optimizing design and manufacture in order to develop commercially and clinically viable products. Vaccine (2007) 25:B47-B60. doi: 10.1016/j.vaccine.2007.06.006

51. Song W, Kong H-L, Carpenter H, Torii H, Granstein R, Rafii S, et al. Dendritic cells genetically modified with an adenovirus vector encoding the cDNA for a model antigen induce protective and therapeutic antitumor immunity. J Exp Med. (1997) 186:1247-56. doi: 10.1084/jem.186.8.1247

52. Terando A, Roessler B, Mulé JJ. Chemokine gene modification of human dendritic cell-based tumor vaccines using a recombinant adenoviral vector. Cancer Gene Ther. (2004) 11:165. doi: 10.1038/sj.cgt.7700671

53. Van den Bergh JMJ, Smits, ELJM, Versteven M, De Reu H, Berneman ZN, Van Tendeloo VFI, et al. Characterization of interleukin-15-transpresenting dendritic cells for clinical use. J Immunol Res. (2017) 2017:1975902. doi: $10.1155 / 2017 / 1975902$

54. Lee JM, Lee M-H, Garon E, Goldman JW, Salehi-Rad R, Baratelli FE, et al. Phase I trial of intratumoral injection of CCL21 genemodified dendritic cells in lung cancer elicits tumor-specific immune responses and $\mathrm{CD}^{+}{ }^{+}$T-cell infiltration. Clin Cancer Res. (2017) 23:4556-68. doi: 10.1158/1078-0432.CCR-16-2821 
55. Wang D, Huang XF, Hong B, Song X-T, Hu L, Jiang M, et al. Efficacy of intracellular immune checkpoint-silenced DC vaccine. JCI Insight (2018) 3:e98368. doi: 10.1172/jci.insight. 98368

56. Hradilova N, Sadilkova L, Palata O, Mysikova D, Mrazkova H, Lischke R, et al. Generation of dendritic cell-based vaccine using high hydrostatic pressure for non-small cell lung cancer immunotherapy. PLoS ONE (2017) 12:e0171539. doi: 10.1371/journal.pone.0171539

57. Montico B, Nigro A, Casolaro V, Dal Col J. Immunogenic apoptosis as a novel tool for anticancer vaccine development. Int J Mol Sci. (2018) 19:594. doi: 10.3390/ijms19020594

58. Hirooka Y, Kawashima H, Ohno E, Ishikawa T, Kamigaki T, Goto S, et al. Comprehensive immunotherapy combined with intratumoral injection of zoledronate-pulsed dendritic cells, intravenous adoptive activated T lymphocyte and gemcitabine in unresectable locally advanced pancreatic carcinoma: a phase I/II trial. Oncotarget (2018) 9:2838-47. doi: 10.18632 /oncotarget.22974

59. Sallusto F, Lanzavecchia A. Efficient presentation of soluble antigen by cultured human dendritic cells is maintained by granulocyte/macrophage colony-stimulating factor plus interleukin 4 and downregulated by tumor necrosis factor alpha. J Exp Med. (1994) 179:1109-18. doi: 10.1084/jem.179.4.1109

60. Sharma MD, Rodriguez PC, Koehn BH, Baban B, Cui Y, Guo G, et al. Activation of p53 in immature myeloid precursor cells controls differentiation into Ly6c+CD103+ monocytic antigen-presenting cells in tumors. Immunity (2018) 48:91-106.e106. doi: 10.1016/j.immuni.2017.12.014

61. Banchereau J, Palucka AK, Dhodapkar M, Burkeholder S, Taquet N, Rolland $\mathrm{A}$, et al. Immune and clinical responses in patients with metastatic melanoma to $\mathrm{CD} 34<\sup >+</$ sup $>$ progenitor-derived dendritic cell vaccine. Cancer Res. (2001) 61:6451-8.

62. Proietto AI, Mittag D, Roberts AW, Sprigg N, Wu L. The equivalents of human blood and spleen dendritic cell subtypes can be generated in vitro from human $\mathrm{CD} 34(+)$ stem cells in the presence of fms-like tyrosine kinase 3 ligand and thrombopoietin. Cell Mol Immunol. (2012) 9:446-54. doi: $10.1038 / \mathrm{cmi} .2012 .48$

63. Vopenkova K, Mollova K, Buresova I, Michalek J. Complex evaluation of human monocyte-derived dendritic cells for cancer immunotherapy. J Cell Mol Med. (2012) 16:2827-37. doi: 10.1111/j.1582-4934.2012.01614.x

64. Kwajah SMM, Schwarz H. CD137 ligand signaling induces human monocyte to dendritic cell differentiation. Eur J Immunol. (2010) 40:1938-49. doi: 10.1002/eji.200940105

65. Dharmadhikari B, Nickles E, Harfuddin Z, Ishak NDB, Zeng Q, Bertoletti A, et al. CD137L dendritic cells induce potent response against cancer-associated viruses and polarize human CD8 + T cells to Tc1 phenotype. Cancer Immunol Immunother. (2018). doi: 10.1007/s00262-018-2144-x

66. Elkord E, Williams PE, Kynaston H, Rowbottom AW. Human monocyte isolation methods influence cytokine production from in vitro generated dendritic cells. Immunology (2005) 114:204-12. doi: 10.1111/j.1365-2567.2004.02076.x

67. Marques GS, Silva Z, Videira PA. Antitumor efficacy of human monocytederived dendritic cells: comparing effects of two monocyte isolation methods. Biol Proced Online (2018) 20:4. doi: 10.1186/s12575-018-0069-6

68. Failli A, Legitimo A, Orsini G, Romanini A, Consolini R. The effects of zoledronate on monocyte-derived dendritic cells from melanoma patients differ depending on the clinical stage of the disease. Hum Vaccin Immunother. (2014) 10:3375-82. doi: 10.4161/hv.29416

69. Takahara M, Miyai M, Tomiyama M, Mutou M, Nicol AJ, Nieda M. Copulsing tumor antigen-pulsed dendritic cells with zoledronate efficiently enhance the expansion of tumor antigen-specific CD8+ T cells via $\mathrm{V} \gamma 9 \gamma \delta \mathrm{T}$ cell activation. J Leukoc Biol. (2008) 83:742-54. doi: 10.1189/jlb.0307185

70. Orsini G, Failli A, Legitimo A, Adinolfi B, Romanini A, Consolini R. Zoledronic acid modulates maturation of human monocyte-derived dendritic cells. Exp Biol Med. (2011) 236:1420-6. doi: 10.1258/ebm.2011.011168

71. Wolf A, Rumpold H, Tilg H, Gastl G, Gunsilius E, Wolf D. The effect of zoledronic acid on the function and differentiation of myeloid cells. Haematologica (2006) 91:1165-71.

72. Kreiter S, Selmi A, Diken M, Koslowski M, Britten CM, Huber C, et al. Intranodal vaccination with naked antigen-encoding rNA elicits potent prophylactic and therapeutic antitumoral immunity. Cancer Res. (2010) 70:9031-40. doi: 10.1158/0008-5472.CAN-10-0699

73. Verdijk P, Aarntzen EHJG, Lesterhuis WJ, Boullart ACI, Kok E, van Rossum MM, et al. Limited amounts of dendritic cells migrate into the T-cell area of lymph nodes but have high immune activating potential in melanoma patients. Clin Cancer Res. (2009) 15:2531-40. doi: 10.1158/1078-0432.CCR-08-2729

74. Lowenfeld L, Mick R, Datta J, Xu S, Fitzpatrick E, Fisher CS, et al. Dendritic cell vaccination enhances immune responses and induces regression of HER $2<\sup >$ pos $</$ sup $>$ DCIS independent of route: results of randomized selection design trial. Clin Cancer Res. (2017) 23:2961-71. doi: 10.1158/1078-0432.CCR-16-1924

75. Mitchell DA, Batich KA, Gunn MD, Huang M-N, Sanchez-Perez L, Nair SK, et al. Tetanus toxoid and CCL3 improve DC vaccines in mice and glioblastoma patients. Nature (2015) 519:366-9. doi: 10.1038/nature14320

76. Therasse P, Arbuck SG, Eisenhauer EA, Wanders J, Kaplan RS, Rubinstein L, et al. New guidelines to evaluate the response to treatment in solid tumors. JNCI (2000) 92:205-16. doi: 10.1093/jnci/92.3.205

77. Eisenhauer EA, Therasse P, Bogaerts J, Schwartz LH, Sargent D, Ford R, et al. New response evaluation criteria in solid tumours: revised RECIST guideline (version 1.1). Eur J Cancer (2009) 45:228-47. doi: 10.1016/j.ejca.2008.10.026

78. Aerts JGJV, de Goeje PL, Cornelissen R, Kaijen-Lambers MEH, Bezemer K, van der Leest $\mathrm{CH}$, et al. Autologous dendritic cells pulsed with allogeneic tumor cell lysate in mesothelioma: from mouse to human. Clin Cancer Res. (2018) 24:766-76. doi: 10.1158/1078-0432.CCR-17-2522

79. Lee J-H, Tak WY, Lee Y, Heo M-K, Song J-S, Kim H-Y, et al. Adjuvant immunotherapy with autologous dendritic cells for hepatocellular carcinoma, randomized phase II study. Oncoimmunology (2017) 6:e1328335. doi: 10.1080/2162402X.2017.1328335

80. Anguille S, Van de Velde AL, Smits EL, Van Tendeloo VF, Juliusson G, Cools $\mathrm{N}$, et al. Dendritic cell vaccination as postremission treatment to prevent or delay relapse in acute myeloid leukemia. Blood (2017) 130:1713-21. doi: 10.1182/blood-2017-04-780155

81. Gross S, Erdmann M, Haendle I, Voland S, Berger T, Schultz E, et al. Twelveyear survival and immune correlates in dendritic cell-vaccinated melanoma patients. JCI Insight (2017) 2:e91438. doi: 10.1172/jci.insight.91438

82. Obermajer N, Urban J, Wieckowski E, Muthuswamy R, Ravindranathan R, Bartlett DL, et al. Promoting the accumulation of tumor-specific $\mathrm{T}$ cells in tumor tissues by dendritic cell vaccines and chemokine-modulating agents. Nat Protoc. (2018) 13:335. doi: 10.1038/nprot.2017.130

83. Cayeux S, Richter G, Becker C, Pezzutto A, Dörken B, Blankenstein T. Direct and indirect T cell priming by dendritic cell vaccines. Eur J Immunol. (1999) 29:225-34. doi: 10.1002/(SICI)1521-4141(199901)29:01\&lt;225::AIDIMMU225\&gt;3.0.CO;2-W

84. Shinagawa N, Yamazaki K, Tamura Y, Imai A, Kikuchi E, Yokouchi H, et al. Immunotherapy with dendritic cells pulsed with tumor-derived gp96 against murine lung cancer is effective through immune response of CD8+ cytotoxic T lymphocytes and natural killer cells. Cancer Immunol Immunother. (2008) 57:165-74. doi: 10.1007/s00262-007-0359-3

85. Prue RL, Vari F, Radford KJ, Tong H, Hardy MY, D’Rozario R, et al. A phase I clinical trial of CD1c (BDCA-1)+ dendritic cells pulsed with HLA-A*0201 peptides for immunotherapy of metastatic hormone refractory prostate cancer. J Immunother. (2015) 38:71-6. doi: 10.1097/CJI.0000000000000063

86. Laoui D, Keirsse J, Morias Y, Van Overmeire E, Geeraerts X, Elkrim Y, et al The tumour microenvironment harbours ontogenically distinct dendritic cell populations with opposing effects on tumour immunity. Nat Commun. (2016) 7:13720. doi: 10.1038/ncomms 13720

87. Broz M, Binnewies M, Boldajipour B, Nelson A, Pollock J, Erle D, et al. Dissecting the tumor myeloid compartment reveals rare activating antigen presenting cells, critical for T cell immunity. Cancer Cell (2014) 26:638-52. doi: 10.1016/j.ccell.2014.09.007

88. Salmon H, Idoyaga J, Rahman A, Leboeuf M, Remark R, Jordan S, et al. Expansion and activation of CD103(+) dendritic cell progenitors at the tumor site enhances tumor responses to therapeutic PD-L1 and BRAF inhibition. Immunity (2016) 44:924-38. doi: 10.1016/j.immuni.2016.03.012

89. Pruneri G, Vingiani A, Denkert C. Tumor infiltrating lymphocytes in early breast cancer. The Breast (2018) 37:207-14. doi: 10.1016/j.breast.2017.03.010 
90. Desmedt C, Salgado R, Fornili M, Pruneri G, Van den Eynden G, Zoppoli $\mathrm{G}$, et al. Immune infiltration in invasive lobular breast cancer. JNCI (2018) 110:768-76. doi: 10.1093/jnci/djx268

91. Wu Y, Yuan L, Lu Q, Xu H, He X. Distinctive profiles of tumor-infiltrating immune cells and association with intensity of infiltration in colorectal cancer. Oncol Lett. (2018) 15:3876-82. doi: 10.3892/ol.2018.7771

92. Pagès F, Galon J, Dieu-Nosjean MC, Tartour E, Sautès-Fridman C, Fridman WH. Immune infiltration in human tumors: a prognostic factor that should not be ignored. Oncogene (2009) 29:1093. doi: 10.1038/onc.2009.416

93. Gartrell RD, Marks DK, Hart TD, Li G, Davari DR, Wu A, et al. Quantitative analysis of immune infiltrates in primary melanoma. Cancer Immunol Res. (2018) 6:481-93. doi: 10.1158/2326-6066.CIR-17-0360

94. Tahkola K, Mecklin J-P, Wirta E-V, Ahtiainen M, Helminen O, Böhm J, et al. High immune cell score predicts improved survival in pancreatic cancer. Virchows Archiv. (2018) 472:653-65. doi: 10.1007/s00428-018-2297-1

95. Vo M-C, Nguyen-Pham T-N, Lee H-J, Lakshmi TJ, Yang S, Jung S-H, et al. Combination therapy with dendritic cells and lenalidomide is an effective approach to enhance antitumor immunity in a mouse colon cancer model. Oncotarget (2017) 8:27252-62. doi: 10.18632/oncotarget.15917

96. Chang L, Zhang Z, Chen F, Zhang W, Song S, Song S. Irradiation enhances dendritic cell potential antitumor activity by inducing tumor cell expressing TNF- $\alpha$. Med Oncol. (2017) 34:44. doi: 10.1007/s12032-016-0864-3

97. Rossowska J, Anger N, Szczygie,ł A, Mierzejewska J, Pajtasz-Piasecka E. Intratumoral lentivector-mediated TGF- $\beta 1$ gene downregulation as a potent strategy for enhancing the antitumor effect of therapy composed of cyclophosphamide and dendritic cells. Front Immunol. (2017) 8:713. doi: 10.3389/fimmu.2017.00713

98. Inogés $\mathrm{S}$, Tejada $\mathrm{S}$, de Cerio AL-D, Pérez-Larraya JG, Espinós J, Idoate $\mathrm{MA}$, et al. A phase II trial of autologous dendritic cell vaccination and radiochemotherapy following fluorescence-guided surgery in newly diagnosed glioblastoma patients. J Transl Med. (2017) 15:104. doi: 10.1186/s12967-017-1202-z

Conflict of Interest Statement: JA: speakers fee and consultancy Eli-Lilly, Boehringer Ingelheim, MSD, BMS, Astra Zeneca, Amphera, Roche; Stock owner Amphera b.v.

The remaining authors declare that the research was conducted in the absence of any commercial or financial relationships that could be construed as a potential conflict of interest.

Copyright (c) 2018 Huber, Dammeijer, Aerts and Vroman. This is an open-access article distributed under the terms of the Creative Commons Attribution License (CC $B Y)$. The use, distribution or reproduction in other forums is permitted, provided the original author(s) and the copyright owner(s) are credited and that the original publication in this journal is cited, in accordance with accepted academic practice. No use, distribution or reproduction is permitted which does not comply with these terms. 